\title{
Geochemistry and Petrogenetic Features of Metasediments in Northern Part of Kushaka and Birnin Gwari Schist Belts NW Nigeria
}

\author{
Kehinde Oluyede $^{1} \quad$ Garba Ibrahim $^{1} \quad$ Umar Danbatta $^{1} \quad$ Paul Ogunleye $^{1} \quad$ Urs Klötzli $^{2}$ \\ 1.Department of Geology, Ahmadu Bello University Zaria, Nigeria \\ 2.Department of Lithospheric Research, University of Vienna, Austria
}

\begin{abstract}
The Kushaka and Birnin Gwari metasediments and associated banded iron formations constitute important lithological units within the Precambrian Basement Complex. They were studied to evaluate their compositional characteristics and petrogenesis in order to contribute further to the understanding of the geodynamic evolution of Nigeria's Schist belts. The Kushaka metasediments comprise quartzite, graphite and sulphur bearing staurolitemuscovite quartz schist interbedded with Banded Iron Formations (BIFs) while the Birnin Gwari schist comprise staurolite-biotite quartz schists with lithic (angular to rounded clastic quartz, schistose, volcanic and quartzofeldspathic) sandstones. These schists are associated with fissile and ferruginous quartzite, banded and granitic gneisses, basalts and amphibolites. Petrographic work revealed varying proportions of quartz, staurolite, biotite and muscovite with subordinate iron-oxide minerals. Geochemically the metasediments in the Kushaka are enriched in $\mathrm{SiO}_{2}$ (61.23 to 65.99 wt \%) with elevated values of $\mathrm{Al}_{2} \mathrm{O}_{3}(16.53-20.93$ wt \%), $\mathrm{Ba}, \mathrm{V}, \mathrm{W}, \mathrm{La}, \mathrm{Nb}$, $\mathrm{Nd}, \mathrm{Rb}$, Th and $\mathrm{Zr}$; while the Birnin Gwari schists, even though enriched in $\mathrm{SiO}_{2}(63.03$ to 65.13 wt \%), has moderately elevated $\mathrm{Al}_{2} \mathrm{O}_{3}(15.4-15.16 \mathrm{wt} \%)$ values but is depleted these trace elements. Field and geochemical characterization of the Kushaka metasediments suggests peraluminous, tholeiite and calc-alkaline character; arkosic and shale-greywacke sedimentary protoliths derived from quartzose sedimentary and granite-quartz monzonite provenance. Calculated ICV values of 0.52 - 0.99 and occurrences of graphite and sulphur in the Kushaka metasediment suggests shallow stable shelf-type sediment of carbonate and iron formations in a reducing environment with matured sedimentary protolith. The Birnin Gwari metasediments on the other hand have a peraluminous and calc-alkaline character, inherited from shale-greywacke and quartzose sedimentary protoliths derived from granodioritic and granite-quartz monzonite provenance. ICV values of $1.12-1.18$ and angular and volcanic clasts suggest rapid subsidence of basin during genesis and / or tectonic instability in the surrounding environment with immature sedimentary protolith. This is an indication of two contrasting environment in an arc setting with contribution from basaltic and andesitic detritus. Available geochronological data on granite and granitic gneisses have ascribed the Kushaka schist belt to Kibaran and the Birnin Gwari schist belt a Pan-African age.
\end{abstract}

Keywords: Metasediments, protolith, Kushaka, Birnin Gwari, quartzite, provenance, shale, greywacke.

DOI: $10.7176 / \mathrm{JEES} / 11-16-05$

Publication date:June $30^{\text {th }} 2021$

\section{INTRODUCTION}

The Birnin Gwari Schist belt and the underlying quartzo-feldspathic rocks of the Zungeru Formation form a single structural unit named Zungeru-Birnin Gwari Schist Belt. It is a simple N-S syncline, $150 \mathrm{~km}$ long, with the northern part displaced dextrally by a NE-SW transcurrent fault. It is characterized by conspicuous NNE-SSW trending ridges rising over $100 \mathrm{~m}$ above surrounding country, comprising mainly phyllites, mica schists, with which metagreywacke, pebbly schist and metavolcanics are interlayered. The lower part (south of the study area) consists of finely banded phyllites in the west and higher grade biotite-muscovite schists in the east. They are overlain by the Durimi pebbly schist, a metamorphosed mudstone conglomerate (Turner, 1983; Ajibade et al., 2008).

The Kushaka Schist Belt is a metasedimentary succession of schist, phyllites and banded iron formations, intruded by large volumes of granitic rocks engulfing the whole formation and fragmenting it into smaller bodies separated by granites and migmatites (Grant, 1978). The main rock type is semi-pelitic biotite-muscovite schist, in other places containing garnet and staurolite. Other rock types are phyllites, metasiltstone and graphitic schists. Amphibolites are locally very thick, suggesting large volcanic accumulations. Basalt extrusion has been mapped in this belt south of the Kalangai fault (Oluyede et al., 2020).

The northern part of both Kushaka and Birnin Gwari is the focus of this study; here the NE-SW KalangaiZungeru-Ifewara (KZI) transcurrent fault dextrally displaced the Birnin Gwari schist belt to the south while it cuts through the whole Kushaka schist belt. Both schist belts have two contrasting structural styles (Fig. 1C). Birnin Gwari metasediments are simple, monocyclic and interpreted as a sedimentary cover infolded during Pan-African event into basement complex, while the Kushaka metasediments are complex and polycyclic and believed to have occurred with the gneisses and migmatites (Grant, 1978). Both belts are of different ages, and are separated by the 
Migmatite-Gneiss-Quartzite Complex. There has been no agreement on the delineation, geological nomenclature, geochemistry and geodynamic setting of this major rock unit of the Nigerian Precambrian Basement Complex (Okunlola and Okoroafor, 2009). This work is an attempt to highlight the geochemical and petrogenetic features of this part of the Kushaka and Birnin Gwari schist belts in order to gain understanding of the evolution of this major rock unit of the Precambrian basement of Nigeria.

\section{REGIONAL GEOLOGICAL SETTING}

The N-S trending Nigerian schist belts are over $400 \mathrm{~km}$ in width and over $1000 \mathrm{~km}$ in length, and lie in the western part of the Precambrian basement complex (an ancient shield reworked in the Pan-African). They are predominantly composed of metamorphosed pelitic to semi-pelitic rocks but each belt differs in the amount of such lithologies as conglomerates, and greywackes, quartzites, meta conglomerates, mafic to ultramafic rocks, calc silicate rocks, marble, metavolcanics and banded iron formations (BIFs). The rock associations differ from one belt to the other. The schist belts are considered to be Upper Proterozoic supracrustal rocks which have been infolded into a migmatite gneiss complex. Syntectonic to late tectonic granitoids (Older Granite) intruded both the migmatite gneiss complex and the schist belts (McCurry, 1976; Rahaman, 1988; Garba, 2002; Mucke, 2005; Danbatta 2008 b) (Fig 1).

Two types have previously been identified, the older metasediment (predominant in southwest Nigeria) and the younger (low-medium grade) metasedments (predominant in northwest Nigeria). However, it is now known that schist belts also extend eastwards of $8^{0}$ meridian (Ajibade, 1976; Emeronye, 1988; Eneh et al., 1989; Ekwueme and Shing, 1987), exhibiting distinct petrological, structural and geochemical characteristics.

Presently, schist belts have been identified namely: Iseyin-Oyan, Ife-Ilesha, Igarra and Egbe-Isanlu and Obajana in the southwest (Rahaman, 1976; Odeyemi, 1977; Elueze, 1981; Annor et al., 1995; Olobaniyi, 2003; Okunlola and Okoroafor, 2009; Adegbuyi et al., 2017). The Lokoja-Jakura, Toto-Gadabuike belts (Muotoh et al., 1988; Elueze, 1981; Okunlola, 2001); the Kushaka, Birnin Gwari, Malumfashi, Wonaka, Kazaure, Maru, Anka, and Zuru in the northwest (McCurry, 1976; Fitches et al., 1985; Turner, 1983; Danbatta, 1999; 2008b; Alaku et al., 2017) and Obudu schist belt recently highlighted in the southeast (Ekwueme \& Shing, 1987; Asinya et al., 2016) (Fig. 1C). The schist belts occur as series of antiform and synformal troughs and forming prominent strike ridges, subsequent erosion and deep weathering has led to its been poorly exposed. The belts are intercalated with relics of migmatites and gneisses and/or intruded granite which separate or lie within them.

The Nigeria's schist belt is believed to have evolved as a result of an initial continental extensional stage culminating in rift openings and sedimentation with contemporaneous magmatism in the basins. These processes were followed by basin inversion which led to the deformation of sediments (Ajibade, et.al., 1987; Elueze, 1992; Danbatta, 2008b). Most of the postulated models recognize that the belts formed in discrete basins, usually demarcated by basement uplifts, and comprise significantly distinct lithological associations. Geochemical parameters of both the metasediments and the mafic rocks are used to constrain their tectonic setting. Both ensialic and ensimatic models have been postulated (Olade and Elueze, 1979; Ajibade and Wright, 1989; Danbatta, 2008b).

\section{STUDY AREA}

The study area covers a total area of 2,809 square kilometers and lies in the north western part of Nigeria comprising parts of the Kushaka and Birnin Gwari schist belts. It falls within 1:100,000 Kushaka Sheet 122 and bounded by latitudes $10^{\circ} 15^{\prime \prime} \mathrm{N}$ and $11^{\circ} 00^{\prime \prime} \mathrm{N}$ and longitudes $6^{0} 30^{\prime \prime} \mathrm{E}$ and $7^{0} 00^{\prime \prime} \mathrm{E}$ (Fig. 1). The area is underlain predominantly by four main lithologies: (i) Migmatite-Gneiss-Quartzite suite represented by dioritic, granodioritic, granitic and granitic gneisses with fissile and ferruginous quartzites and banded iron formation (BIF); the schist belts represented by (ii) the Kushaka graphite and sulphur bearing staurolite, biotite and muscovite quartz schist and in places inter-banded with iron formations; iii) the Kushaka Gneiss Complex represented by extrusive basalts, staurolite and muscovite gneiss and banded iron formation (BIF) and (iv) syn- tectonic and late- orogenic biotitehornblende syenite (BHS) and biotite-hornblende granite (BHG) in the Kushaka schist belt and biotite muscovite granite (BMG) in the Birnin Gwari schist belt area.

\section{MATERIALS AND METHODS}

Fifteen representatives (eight in Kushaka and seven in Birnin Gwari) metasediments samples were carefully selected and thin sections were prepared and petrographic studies of different rock types were done using a petrographic research microscope at the Department of Geology, Ahmadu Bello University, Zaria. Modal compositions of the rocks were estimated from thin section studies using the JMicrovision software of Nicholas Roduit version 1.2.7. (2002-2008). Modal analyses of the metasedimentary rocks are given in Table 1.

Seven representative samples were analysed (Table 2) comprising each mappable lithologic unit which include ferruginous quartzite, staurolite, biotite and muscovite quartz schists. About $1 \mathrm{~kg}$ of each sample was broken into pieces with a hammer and crushed into smaller pieces with a jaw-crusher. The samples were thereafter pulverized in a disc mill for about two minutes. Each pulverised sample was thoroughly homogenized to obtain a 
representative portion. The samples were thereafter sent to laboratories for whole-rock geochemistry in the Department of Geological Sciences, University of Vienna, Austria.

Rocks were crushed and grounded to the finest powder possible in an agate (or tungsten carbide) swing mill for the whole X-ray-fluorescence analysis. Major elements were determined by the fused bead method on calcined rock powder fused with lithium tetraborate as flux to form a glass bead. Trace elements used the pressed pellet method directly on the crushed and milled rock powder mixed with polyvinyl alcohol as a binding agent. The element analyses are performed on a sequential X-Ray spectrometer PHILIPS PW2404 using a super-sharp endwindow tube with a Rh-anode and a programmable $4 \mathrm{~kW}$ generator $(60 \mathrm{kV}$ max., $125 \mathrm{~mA}$ max.; iso-Watt-switching), with accompanying PANalytical software.

\section{RESULTS AND DISCUSSIONS}

\subsection{Field Occurrence and Petrography}

The Kushaka metasediments comprise staurolite, biotite and muscovite quartz schists interbedded with banded iron formations (BIFs). Two varieties are recognized in the field. (i) The fine grained grey to silvery grey staurolitemuscovite types confined to the river channels in Kugu area; (ii) The yellowish to grayish type around Sabo-Layi is graphite, sulphur bearing, (minerals in hand specimen) biotite schist. Graphite is silvery grey to black colour with greasy feel and smudges the hand when touched, but may have been transformed or altered to magnetite and haematite as opaque minerals as observed under the microscope (Fig. 2 and 3).

The staurolite-muscovite schist in Kushaka around Kugu consists predominantly of staurolite (30\%), ironoxide (5\%), quartz (30\%), K-feldspar (20\%) and muscovite $(10 \%)$ embedded in a quartz, feldspar and muscovite matrix (Table 1). Staurolite occurs as pale brown (in plain polars and with yellow, orange, purple and blue interference colours in cross polars), euhedral six-sided elongated crystals and rounded edges with high relief from the groundmass (Fig. 2 A and B). The staurolite is also characterized by quartz inclusions and dotted with iron-ore crystals. Muscovite occurs as fibrous and acicular crystals stacked between the staurolite minerals. Iron-ore occurs as euhedral and subhedral crystal disseminations. Medium grain quartz crystals are elongated and prismatic tightly joined together with wavy extinction. Accessory mineral is magnetite.

Quartzites: Consists of greyish white fissile and reddish brown ferruginous types. The grayish white and fissile rock occur as poorly exposed low lying ridges in Nasarawa Kwona area of Kushaka schist belt. Where exposed, they are aligned in the N-S foliation direction. The ferruginous quartzite occurs as iron-formation interbedded with quartzite. They are characterized by clear microfolds, crenulation cleavages, nearly vertical dips and well defined schistocity. They are well exposed in Maganda area (Plate I). In the adjoining Kusheriki, south west of the study area, they are interlayered with phyllites.

Banded Iron Formation (BIF) is exposed as series of $\mathrm{N}-\mathrm{S}$ trending ridges and as isolated hills with elevation of $\geq 600 \mathrm{~m}$ in Sabo-Layi, Kugu and Galadimawa area. Where they are interbedded with the schist, exposures show iron-formation occurrence with semi-pellitic schist and the iron concretions at the top. Concretionary ironstone at the top of the isolated hill is composed of cherts and iron-rich minerals which form alternating bands (Fig. 1).

Amphibolites: Amphibolites occurs as dykes in the Kungwi area, showing characteristic brittle deformation with fragmented boulders. The major one extend for over $1 \mathrm{~km}$ in length and $>6 \mathrm{~m}$ in width trending N $160^{\circ}$ direction. It is a fine grained dark coloured rock with acicular quartz occurring as bands $(1-2 \mathrm{~mm})$, trending in the general $\mathrm{N}$ $-\mathrm{S}$ foliation direction. There are others of smaller length and width.

The Birnin Gwari metasediment occurs as an elongate, N-S trending metasedimentary outcrop of $430 \mathrm{~m}$ elevation, and as a whale back outcrop exposed along Kogi Kusheriki river channels, through Mando (Fig. 2C). It consists of staurolite and biotite quartz schists with lithic sandstone (clastic quartz, schistose, volcanic and quartzofeldspathic materials) (Fig. 2). Four types based on field occurrence have been observed:

The bluish grey fine grained rock with clast ( $2 \mathrm{~mm}$ to $5 \mathrm{~cm}$ and making up to $25 \%$ of the constituent of the rock), aligned in the foliation direction, showing flow structure. (ii) Light grey, mediun grained rock with dark minerals evenly distributed, the clast making up about $40 \%$ is angular to rounded and flattened, and are poorly sorted with range of particle sizes from sand to cobbles. (iii) Dark grey colour, fine grained rock characterized by ripple marks cross bedding and cross lamination, typical of sedimentary structures. (iv) Dark fine grained with granular texture without clastic materials, close to the Mando granitic intrusion with granitic dyke occurring in the biotite and ironrich metasediment (Plates I).

The staurolite-biotite schist variety in Birnin Gwari occurs as slightly foliated fine to medium grained rock dark coloured rock with clastic materials consisting of staurolite (30\%), quartz (30\%), K-feldspar (20\%), muscovite (10\%) and iron-oxide (5\%). Biotite crystal is sub-hedral to anhedral and sometimes aligned with quartz and staurolite minerals (Table 1) (Fig. 3D).

\subsection{Geochemistry}

Whole-rock major and trace elements data of representative rock samples of the metasediments are represented in Table 2 and 3. 


\section{Major Elements}

Analytical results (Table 2) indicate that $\mathrm{SiO}_{2}$ value ranges both in the Kushaka and Birnin Gwari metasediments is $61.23-65.99 \mathrm{wt} \%$ They are are generally siliceous and falls within the limits for average schistose rocks of Nigeria (Elueze, 1979; Olobaniyi, 2002) including the Obudu schist in the southeast (Obioha and Ekwueme, 2012). Ferruginous quartzite has $62.61 \mathrm{wt} \%$, chemically similar to those for the Jebba quartzite, micaceous quartzite of central Nigeria (Okonkwo, 2006) and quart-sandstones (Blatt, et. al., 1972) but less silicious compared to the Okemesi quartzite (Okunlola and Okoroafor, 2009). The banded iron formation has $50.98 \mathrm{wt} \%$.

Kushaka metasediments exhibit high $\mathrm{Al}_{2} \mathrm{O}_{3}$ content with a range of $17.71-19.72 \mathrm{wt} \%$ for the staurolitemuscovite schist, high value for the ferruginous quartzites $\left(20.93 \mathrm{wt} \%\right.$ ), but moderate $\mathrm{Al}_{2} \mathrm{O}_{3}$ content for the Birnin Gwari staurolite schist $(15.40-15.16 \mathrm{wt} \%)$. The high $\mathrm{Al}$ enrichment in the $\mathrm{Al}_{2} \mathrm{O}_{3}$ reflects their composition by aluminous clay minerals and pellitic nature of the metasediments. The $\mathrm{K}_{2} \mathrm{O}$ content $(2.36-4.2 \mathrm{wt} \%)$ is higher than the $\mathrm{Na}_{2} \mathrm{O}$ content $\left(0.98-2.29\right.$ wt \%). The $\mathrm{K}_{2} \mathrm{O} / \mathrm{Na}_{2} \mathrm{O}$ reflects probable secondary addition of potassium $(\mathrm{K}-$ metasomatism) during metamorphism (Fedo et al., 1995).

$\mathrm{TiO}_{2}$ content ranges from $0.74-1.01 \mathrm{wt} \%$ in Kushaka to $0.92-0.97 \mathrm{wt} \%$ in Birnin Gwari metasediments. $\mathrm{Fe}_{2} \mathrm{O}_{3}$ ranges from $4.92-7.96$ wt \% in Kushaka to $6.62-7.3$ wt \% in Birnin Gwari metasediments; with 29.22 wt $\%$ for the banded iron formation. $\mathrm{MnO}$ in Kushaka is $0.05-0.13 \mathrm{wt} \%$ while Birnin Gwari is $0.11-0.12 \mathrm{wt} \%$. $\mathrm{MgO}$ is $0.18-2.97 \mathrm{wt} \%$ in Kushaka and $2.17-3.31 \mathrm{wt} \%$ in Birnin Gwari metasediments. CaO ranges from 0.17 -0.84 wt \% in Kushaka to $1.69-1.92$ wt \% in Birnin Gwari. Generally, $\mathrm{TiO}_{2}, \mathrm{Fe}_{2} \mathrm{O}_{3}, \mathrm{MnO}, \mathrm{MgO}$ and $\mathrm{CaO}$ shows moderate to high concentration in the metasediments; however values in Birnin Gwari are higher compared to Kushaka metasediments. This reflects the high content of ferromagnesian minerals in both metasediments. Variable $\mathrm{MgO}$ and $\mathrm{CaO}$ contents perhaps indicate shales and clays that are both carbonate-free as well as containing about $30 \%$ carbonates. $\mathrm{MgO}$ content in excess of $\mathrm{CaO}$ content by $<0.6 \mathrm{wt} \%$ is typical of carbonatefree protolith (Ekwueme, 1985).

\section{Trace Elements}

The Kushaka metasediments has fairly high Ba with a range of 599 - 974.8 ppm, but a low range in Birnin Gwari with 27.6 - $32.2 \mathrm{ppm}$. Rb shows high concentration $(116-153.6 .8 \mathrm{ppm})$ in Kushaka compared to Birnin Gwari (13.5 - 14.4 ppm). Zr also revealed high concentration (187.3 - 212.6 ppm) in Kushaka compared to Birnin Gwari metasediments $(32.7-41.9 \mathrm{ppm})$. The high $\mathrm{Ba}, \mathrm{Rb}$ and $\mathrm{Zr}$ concentration in Kushaka are within the range of supracrustal rocks(Brown et al., 1979) and similar to the semi pellitic schist of Isanlu area and Ijero Ekiti metasediments (Olobaniyi, 2002; Akinola and Okunlola, 2012); The high Ba indicates K-feldspar rich source rocks in Kuskaka and low Ba in Birnin Gwari indicates K-feldspar poor source rocks. The low $\mathrm{Ba}, \mathrm{Rb}$ and $\mathrm{Sr}$ values in Birnin Gwari is similar to the Okemesi quartzites (Okunlola and Okoroafor, 2009).

The concentration of $\mathrm{Rb}$ especially in the Kushaka metasediments is similar to their derivation from clay and shales which is a reflection of their origin. $\mathrm{Rb} / \mathrm{Sr}$ ratio of $>0.4 \%$ in Birnin Gwari metasediments is typical for pelitic metasediments (Van De Kamp, 1968). High $\mathrm{Zr}$ concentration is a reflection of the presence of detrital zircon in the Kushaka metasediments and lack of it in the Birnin Gwari metasediments (Elueze, 1981). Sr content is in the range of $99.2-127.9 \mathrm{ppm}$ in the Kushaka metasediments and $134-557.6 \mathrm{ppm}$ in the Birnin Gwari schists. Zn concentration is $32.5-109.1 \mathrm{ppm}$ in the Kushaka metasediments and $32.7-41.9 \mathrm{ppm}$ in the Birnin Gwari schist. Generally, Ba, V, W, La, Nb, Nd, Rb, Th and $\mathrm{Zr}$ are more enhanced in Kushaka metasediments than in Birnin Gwari metasediments. Enrichment of incompatible high field strength elements (HFSE) and large ion lithophile elements (LILE) in the Kushaka metasediments compared to Birnin Gwari metasediments may have been responsible for the mineralization of the earlier.

\subsection{Petrogenetic Characteristics}

The petrogenetic character of the rocks as established on the $\mathrm{Na}_{2} \mathrm{O} / \mathrm{Al}_{2} \mathrm{O}_{3}$ versus $\mathrm{K} 2 \mathrm{O} / \mathrm{Al}_{2} \mathrm{O}_{3}$ plot (after Garrels and Mackenzie, 1971) (Fig. 4A) that shows that both Kushaka and Birnin Gwari metasediments plot in the sedimentary/metasedimentary field, implying that the rocks are largely of sedimentary origin, hence postulating a common origin for the protolith of the rock units. In the $\mathrm{MgO}-\mathrm{CaO}-\mathrm{Al}_{2} \mathrm{O}_{3}$ diagram of Leyleroup et al., 1977 (Fig. 4B) shows the entire metasediments plot outside the magmatic field also supporting the sedimentary antecedent of these rocks. These petrogenetic character of the Kushaka and Birnin Gwari metasediments is similar to those of Ilesha (Elueze, 1981), Lokoja-Jakura (Okunlola, 2003), Sepeteri (Okunlola et al., 2006), Birnin-Gwari schist (Ajibade et al., 2003), Okemesi (Okunlola and Okoroafor, 2009).

$\mathrm{Al}_{2} \mathrm{O}_{3} /\left(\mathrm{CaO}+\mathrm{Na}_{2} \mathrm{O}+\mathrm{K}_{2} \mathrm{O}\right)$ versus $\mathrm{Al}_{2} \mathrm{O}_{3} / \mathrm{Na}_{2} \mathrm{O}+\mathrm{K}_{2} \mathrm{O}$ geochemical data of the metasediments (after Maniar and Piccoli, 1989) (Fig. 5A) are dominantly in the peraluminous field. This consistent with the molecular proportion of $\mathrm{Al}_{2} \mathrm{O}_{3}>\left(\mathrm{CaO}+\mathrm{Na}_{2} \mathrm{O}+\mathrm{K}_{2} \mathrm{O}\right)$, thus corroborating the peraluminous character of both Kushaka and Birnin Gwari metasediments.

The $\left(\mathrm{Na}_{2} \mathrm{O}+\mathrm{K}_{2} \mathrm{O}\right)-\mathrm{Fe}_{2} \mathrm{O}_{3}-\mathrm{MgO}$ ternary plot (Fig. 5B) (after Irvine and Baragar, 1971) discriminates the metasediment of Birnin Gwari as having a calc-alkaline affinity and Kushaka as tholeiitic and calc-alkaline. This 
shows that metasediments of Birnin Gwari area have a petrogenetic character that is similar to those in Okemesi area, while Kushaka metasediment bear similarity with the Sepeteri amphibolitic schist (Okunlola et al., 2005). The composition of the metasediments (Table 2), when plotted in the ACF diagram of Winkler (1967) (Fig. 6A), shows ferruginous quartzite (KFQ1) and biotite-muscovite quartz schist (KKSc1) samples (around Sabo Layi area in the Kushaka metasediments) plot at the edge of Al-rich clay and shale and clay (1a) and shales free of carbonate (1b). Kugu biotite and staurolite-muscovite schist (KKSc 2 and KKSc 3) of Kushaka metasediment, and staurolitebiotite schists (KBGSc1 and KBGSc 2) of the Birnin Gwari metasediment both plot in the field 1b (between arrows) of Winkler (1967), indicating shales and clays containing about $30 \%$ carbonates; no sample plots in the field 2 (Wyoming greywackes), while banded iron formation samples plot close to field 3 (basaltic and andesitic rocks) (Fig. 6A). This shows that metasediments of Kushaka and Birnin Gwari area are possibly derived from clays and shales which could have been contaminated by mantle derived rocks of basaltic composition from the Kushaka Gneiss Complex. Similarly the chemical composition of the Kushaka and Birnin Gwari metasediments plotted in the ACF diagram (after Miyashiro, 1973) (Fig. 4b) reveal a shale protolith. The data falls in the field of shalegraywackes, which suggest they originated from shale; clay and shale also shows mixed nature of these sediments. When the Kushaka and Birnin Gwari metasediments are plotted on the $\mathrm{CaO}-\mathrm{Na}_{2} \mathrm{O}-\mathrm{K}_{2} \mathrm{O}$ diagram (Fig. 7A), and the fields showing the compositional variations in acid to basic rocks are superimposed (Condie, 1967), Kushaka metasediments plot in the field of granite -quartz-monzonite, while Birnin Gwari metasediments plot at the edge of the field of granodiorite/ granite -quartz-monzonite indicating that their shale-arkose protoliths were derived essentially from a granitic-quartz-monzonitic source.

The $\mathrm{Na}_{2} \mathrm{O}$ versus $\mathrm{K}_{2} \mathrm{O}$ plot of metasediment (after Pettijohn, 1975) (Fig. 8A) further distinguish Kushaka schist into the arkosic and Birnin Gwari schist into the greywacke field. As confirmed by (Pettijohn, 1957), the average composition of shale show high abundances of $\mathrm{Al}_{2} \mathrm{O}_{3}$ and $\mathrm{K}_{2} \mathrm{O}$ which is generally in excess of $\mathrm{Na}_{2} \mathrm{O}$. $\mathrm{K}_{2} \mathrm{O}>\mathrm{Na}_{2} \mathrm{O}$ is used to indicate shale, and high proportion of $\mathrm{K}$-bearing rock forming minerals such as mica, $\mathrm{K}$ feldspar, illite, compared to Na-feldspar which is unstable prior to metamorphism. On the $\mathrm{Al}_{2} \mathrm{O}_{3}-\mathrm{CN}-\mathrm{K}_{2} \mathrm{O}$ plot, (Fig. 8B) the ferruginous quartzite, staurolite, biotite and muscovite quartz schists all of the Kushaka metasediment plot close to the illite fields while the staurolite and biotite quartz schist of Birnin Gwari metasediment plot close to the average shale. Banded iron formations straddle between kaolinite and smectite.

The results of the Chemical Index of Alteration (CIA) (Nesbitt \& Young 1982; Okunlola, 2003) reveal values of $80.84 \%$ for ferruginous quartzite, $73.36-78.56 \%$ for Kushaka metasediment, $67.13-70.51 \%$ for Birnin Gwari metasediments and $89.64 \%$ for the banded iron formation (Table 2). These values point to relatively intense chemical weathering of the source rocks.

The Index of Compositional Variability (ICV) (Cox \& Lowe, 1995) measures the abundance of alumina relative to other constituents of the rock, except $\mathrm{SiO}_{2}$. Compositionally immature pelitic rocks have high ICV, whereas mature pelititc rocks with very little non silicates or those rich in kaolinite group clay minerals possess low values $(<0.6)$ (Elueze \& Okunlola, 2003). In the study area, Kushaka ferruginous quartzite; biotite, staurolitemuscovite quartz schist; Birnin Gwari staurolite and biotite schist and Kushaka banded iron formation shows 0.52 , $0.59-0.99,1.12-1.18$ and 3.11 respectively (Table 3 ). The calculated ICV value for the Kushaka ferruginous quartzite $(0.52)$ and biotite, staurolite and muscovite quartz schist $(0.59-0.99)$ shows the matured nature of the sedimentary protolith prior to metamorphism; whereas calculated ICV value for the Birnin Gwari staurolite and biotite schist $(1.12-1.18)$ shows the immatured nature of the sedimentary protolith prior to metamorphism. Mature to moderately mature pelitic metasediments are characteristic of relatively stable cratonic environments, marked by moderate to very intense chemical weathering of first cycle material (Weaver, 1989; Bershad, 1966).

\subsection{Provenance of the protolith and Tectonic Setting}

$\mathrm{Th} / \mathrm{U}$ ratio is also a useful parameter in determining the source characteristics of clastic sedimentary rocks (Roddaz et al., 2006). This ratio ranges between 4.25- 4.30 in present day crust, while its values of 2.6 and 3.8 have been assigned to upper and lower mantle respectively (Cullers and Podkovyrov, 2002). Higher Th/U ratios can also increase in response to oxidative weathering and/or removal of U. Nevertheless, clastic sedimentary rocks derived from the upper crust are characterized by ratio $\geq 4$, whereas ratio $<4$ has been related to a mantle contribution (Roddaz et al., 2006). In the Kushaka metasediments, Th/U ratios vary from $3.40-6.14$ in the staurolite and biotite schist, and 13.75 in the ferruginous quartzite. This suggests that there have been significant proportion of the felsic rocks with mantle contribution from the source region.

The $\mathrm{TiO}_{2}-\mathrm{K}_{2} \mathrm{O}-\mathrm{P}_{2} \mathrm{O}_{5}$ plot (Fig. 7B) (after Pearce et al., 1975) of the biotite muscovite and staurolite schist and ferruginous quartzite confirms continental nature of the sediments while the banded iron confirms oceanic nature of the sediment. The dual continental and oceanic field is a confirmation of the nature of the sediments which underwent metamorphism.

Roser and Korsch (1986) have shown that sandstone-mudstone suits from different tectonic settings can be distinguished on the basis of the $\mathrm{K}_{2} \mathrm{O} / \mathrm{Na}_{2} \mathrm{O}$ and $\mathrm{SiO}_{2} / \mathrm{Al}_{2} \mathrm{O}_{3}$ values and $\mathrm{SiO}_{2}$ contents (Fig $9 \mathrm{~A}$ ). On the $\mathrm{SiO}_{2} / \mathrm{Al}_{2} \mathrm{O}_{3}$ versus $\mathrm{K}_{2} \mathrm{O} / \mathrm{Na}_{2} \mathrm{O}$ plots, all samples of the metasediment, plot in the basaltic and andesitic arc setting, except for 
the Kugu staurolite and muscovite schist which plot in the evolved arc setting - plutonic detritus (Fig 9B). Thus, metasediments of the Kushaka and Birnin Gwari are of arc basaltic and andesitic setting. Basalts and amphibolites have been used as geochemical indicators of the tectonic setting in the Nigerian schist belts as of back-arc tectonic environment, near subduction zone setting (Elueze, 1992; Okunlola et al., 2006; Danbatta and Garba, 2007).

Grant (1978) obtained $\mathrm{Rb}$ - Sr data from Kusheriki granite emplaced across the gneissic envelope in Birnin Gwari and augen gneiss in the Sabon Gayam area of Kushaka schist belt. The Kusheriki granite with low and uniform $\mathrm{Rb} / \mathrm{Sr}$ ratios, and an isochron based on four whole-rock samples and two spatially associated aplite veins gives an age of $500 \pm 4 \mathrm{~m}$. y., with an initial ratio of $0.7119 \pm 0.0002$ (Fig. 7a), ascribing Pan-African age to the Birnin Gwari schist belt. The augen gneiss have high and uniform $\mathrm{Rb} / \mathrm{Sr}$ ratios, and no isochron can be based on them (Fig. 10B). Model ages for the five analysed samples are insensitive to initial $87 \mathrm{Sr} / 86 \mathrm{Sr}$ ratio assumptions, and that the ratio for these rocks lies within limits $0.725+0.02$, the data centroid implies that their ages lie between 730 and $650 \mathrm{~m}$. y., a possibility that rocks from the schist belt was derived from pre-Pan-African rocks.

\section{CONCLUSION}

The Kushaka schist in the study area is composed of quartzite, ferruginous quartzite, graphite and sulphur bearing biotite quartz schist (BQS) and staurolite and muscovite quartz schist (SMQS) interbedded with Banded Iron Formations (BIFs). Birnin Gwari schist comprise staurolite-biotite and staurolite-muscovite quartz schist (SBQS) with angular to rounded clastic quartz, schistose, volcanic and quartzo-feldspathic materials (lithic sandstone).

Kushaka and Birnin Gwari metasediments are of sedimentary origin, hence a common origin for the protolith and dominantly of peraluminous character. Birnin Gwari metasediment has calc-alkaline and Kushaka has tholeiitic and calc-alkaline affinity. Their metasediments are possibly derived from clays and shales which could have been contaminated by other mantle derived rocks. Kushaka metasediment is further distinguished as arkosic while Birnin Gwari metasediment is distinguished as greywacke. Their geochemical composition revealed continental affinities with oceanic contribution and interpreted as reflecting contamination of crustal sources (Elueze, 1985). These belts are ensialic and evolved most probably in a rifted environment. Occurrences of graphite and sulphur in the Kushaka metasediment suggests shallow stable shelf-type sediment of carbonate and iron formations in a reducing environment and matured sedimentary protolith. Angular and volcanic clasts in the greywacke of Birnin Gwari metasediment suggest rapid subsidence of basin during genesis and / or tectonic instability in the surrounding environment and immatured sedimentary protolith prior to metamorphism. These are two contrasting environments in an arc setting with contribution from basaltic and andesitic detritus. This is similar to greywacke rocks of the Isanlu schist belt (Olobaniyi, 2003) and schistose rocks of Okemesi on the eastern side of the Ife-Ilesha schist belt (Okunlola and Okoroafor, 2009) where they suggests a rapidly subsiding basin accompanied contemporaneously with tectonic instability resulting in deformation and fracture in a rifted environment. The metasediments of the Kushaka and Birnin Gwari are of both continental and oceanic affinities. In terms of tectonic setting, the metasediments are of arc basaltic and andesitic setting which evolved most probably in a rifted environment.

Different ages have been assigned to the belts (Kushaka and Birnin Gwari) based on available geochronological data. Kushaka schist belt ascribed to Kibaran and Birnin Gwari schist belt ascribed to PanAfrican (Grant, 1978; Turner, 1983; Ajibade, 2003).

\section{ACKNOWLEDGEMENT}

The authors equally acknowledged the assistance of Mr Adekunle in Birnin Gwari for his assistance as a guide during the field mapping exercise. We are indebted to the staff of Geochronology Laboratory for their efforts in carrying out the geochemical analysis for the whole rock major and trace elements. Insights and contributions of Prof. Abba and Prof. Ajibade in the course of this work are greatly acknowledged. The efforts of Prof. Najime Tavershima, Head, Geology Department, Dr S. S. Magaji, Mr. A.K. Amuda and Mr Animashaun of the Department of Geology, Ahmadu Bello University Zaria are equally acknowledged. The help of Peter Nagl, University of Vienna, with the whole rock geochemical analysis is also acknowledged.

\section{REFERENCES}

Adegbuyi, O., Ogunyele, A.C., Odindu, M., and Erinfolami, T.G. (2017). Geochemical Characteristics and Petrogenesis of Basement Rocks in Idoani Area, Ondo State, Southwestern Nigeria. International Journal of Advanced Geosciences, 5 (2) (2017) 102-108

Ademola, A.Y., Amos, O.O. (2018). Geology, Geochemistry and Petrogenesis of Precambrian Rocks of Part of Sheet 244 of Ado-Ekiti, Southwestern Nigeria. Journal of Environment and Earth Science Vol.8, No.1,

Annor, A.E. (1995): U-Pb zircon age for Kabba-Okene granodiorite gneiss: implications for Nigeria"es basement chronology. Africa Geoscience Review, 2, 101-105.

Ajibade, A.C. (1976): Provisional Classification and Correlation of the schist belt of Northwestern Nigeria. Geology of Nigeria; Kogbe C. A., (ed). Elizabethan Publ. Co., Lagos, 85-90. 
Ajibade. A.C, Woakes, M., and Rahaman M.A (1987): Proterozoic Crustal Development in the Pan-African Regime of Nigeria. In: C. A. Kogbe (edition) "Geology of Nigeria" 2nd revised edition Rock View Nigeria limited, Jos. 57-69.

Alaku, I.O., Moshood, O.I., Agbor, A.T. and Amos, A.A. (2017). Geochemical Characteristic and Petrogenesis of Malumfashi Schist around Tandama Area, North-Western Nigeria. British Journal of Applied Science \& Technology 20(1): 1-14, 2017.

Asinya, E.A., Oden, M.I., Ephraim, B.E., Udinmwen, E. and Edem, S.U. (2016). Mesoscopic Structural Analysis of the Schist Enclaves in Oban Massif, South-Eastern Nigeria. Asian Journal of Physical Sciences 1(1): 1-14, 2016.

Bershad, I. (1966): The effect of a variation in precipitation on the nature of clay mineral formation in soils from acid and basic igneous rocks. Proceedings, International; Clay Conference, 167-173.

Blatt, H., Middleton, C. \& Murra y, R. (1972): Origin of sedimentary rocks. Prentice-Hall Inc. Englewood Cliffs, New Jersey. 643.

Cullers, R.L. and Podkovyrov, V.L. (2002). The source and origin of terrigenous sedimentary

rocks in the Mesoproterozoic Ui group, Southeastern Russia. Precambrian Research. 117(3):157-183.

Danbatta U.A., (1999): Geotectonic evolution of the Kazaure Sciest Belt in the Precambrian Basement of NW Nigeria. Unpublished PhD Thesis, Ahmadu Bello University Zaria, 279-286

Danbatta, U.A. and Garba, M L. (2007). Geochemistry and petrogenesis of Precambrian amphibolites in the Zuru Schist Belt, northwestern Nigeria, Journal of Mining and Geology, vol. 43(1), 23-30

Danbatta, U. A. (2008b). A review of the evolution and tectonic framework of the schist belts of Western Nigeria, West Africa. African Geoscience Review 15, 2, 145-158.

Ekwueme, B.N. (1983). Regional Metamorphism of pelitic rocks of Lokoja, Nigeria. Journal of Geol. 20: 71-77.

Ekwueme, B. N. (1985). Petrology, geochemistry and Rb-Sr geochemistry of Uwet Area, South-eastern Nigeria. Unpublished Ph. D Thesis, University of Nigeria, Nsukka.

Ekwueme , B.N. \& Shing, R., (1987). Occurrence, Geochemistry and Geochronology of mafic-Ultramafic rock in the Obudu Plateau S.E. Nigeria in Srivasta R.K. and Chadta, R. (eds) Magmatism relation to diverse tectonic settings.

Elueze, A. A. (1981). Dynamic metamorphism and oxidation of amphibolites of Tegina Area, North-western Nigeria. Precambrian Research. 14(3):379-388.

Elueze A. A. (1992): Rift System for Proterozoic schist belt in Nigeria. Tectonophysics; Vol. 209, pp 167-169.

Emeronye, B.F. (1988). Appraisal of manganese mineralization around Ikpeshi, Bendel State, Nigeria. Abstract of seminar GSN. 5p.

Eneh, K.E., Mbonu, W.C. \& Ajibade A.C. (1989): The Nigerian metasedimentary belts. Facts, fallacies and New Frontiers. In: Oluyide P.O (ed) Precambrian geology of Nigeria Geol. Surv. Nigeria. 201.

Fedo, C.M., Nesbitt, H.W. and Young, G.M. (1995). Unraveling the effects of potassium metasomatism in sedimentary rocks and paleosols, with implications for paleoweathering conditions and provenance. Geology. 23:921-924

Fitches, W.R., Ajibade A.C., Egbuniwe I.G., Holt R. W., and Wright J.B. (1985): Late Proterozoic Schist Belts and Plutonism in NW Nigeria ${ }^{e e}$, Geological Society of London, 142, 319- 337.

Garba, I. (2002). Late Pan-African tectonics and origin of Gold mineralization and Rare-metal pegmatites in the Kushaka schist belt, northwestern Nigeria. Journal of Mining and Geology. 38, 1, 1-12.

Garrels,R.M., and MacKenzie, F.T. (1971). Evolution of sedimentary rocks. W.W. Norton and Company, New York. 394.

Grant, N.K. Hickman, M., Burkholder, F.R. and Powell, J.L. (1972). Kibaran Metamorphic Belt in the Pan-African Domain of W. Africa. Nature (London). 134, 343-349.

Grant N.K. (1978): Structural distinction between a metasedimentary cover and an underlaying basement in the 600-m.y.-old Pan-African domain of northwestern Nigeria, West Africa. Geological Society of America Berlletin, 89, 50-58.

Irvine, T.N. and Baragar, W.R.A. (1971): A guide to the chemical classification of the common volcanic rocks. Journal of Petrology (17), 589-637.

Maniar, P.D. and Piccoli, P.M. (1989): Tectonic discrimination of granitoids. Geol. Soc. Amer. Bull., Vol. 101, 635-643.

McCurry, P. (1976): Pan-African Orogeny in Northern Nigeria. Geological Society of America Bulletin 82, 32513263.

Miyashiro A. 1973. Metamorphism and metamorphic belts. George Allen \& Unwin Ltd. London. 492.

Mucke, A., 2005. The Nigerian manganese-rich iron-formations and their host rocks: from sedimentation to metamorphism. Journal of African Earth Sciences 41, 407-436.

Muotoh , E.O.G., Oluyide , P.O., Okoro , A.U., Mogbo , O.E.(1998): The Muro Hills banded iron formation G.S.N. Annotated technical reports; 1358, 15-25. 
Nesbitt, H. W. \& Young, G. M. (1982): Early Proterozoic Climates and Plate Motions Infered from Major Element Chemistry of Lutites. Nature 199, 715-717.

Obioha, Y.E. and Ekwueme, B.N. (2011). Petrology and chemical composition of gneisses of Northwest Obudu Plateau, Southeastern Nigeria. Global J. Pure and Applied Sciences, 17 (2), 215 - 226.

Odeyemi, I.B (1977): The basement rocks of Bendel state of Nigeria. Unpublished Ph. D. Thesis. University of Ibadan.

Okonkwo, C.T. (2006): Chemical Evidence for the Sedimentary Origin of Igarra Supracrustal Rocks S.W. Nigeria. Journal of Mining and Geology; Vol. 22, 97-104.

Okunlola, O.A. (2001): Geological and Compositional Investigation of Precambrian Marble Bodies and associated Rocks in the Burum and Jakura areas, Nigeria. Ph. D. Thesis, University of Ibadan, Nigeria, 193.

Okunlola, O.A., Akintola, A.I., Egbeyemi, R.O. (2006): Compositional features and petrogenetic affinity of Precambrian amphibolitic schists of Sepeteri area, southwestern Nigeria. Journal of Geological sciences, 4(2), 199-207.

Okunlola, O.A (2003): Petrochemical and Petrogenetic Characteristics of metasedimentary rocks of Lokoja-Jakura Schist belt, Central Nigeria. Journal of Mining and Geology, 39(1), 21-28.

Okunlola and Okoroafor, (2009). Geochemical and petrogenetic features of schistose rocks of the Okemesi fold belt, Southwestern Nigeria RMZ - Materials and Geoenvironment, Vol. 56, No. 2, 148-162, 148

Olobaniyi, S.O. (2003) Geochemistry of semi politic schist of Isanlu area, Southwestern Nigeria: Implication for the geodynamic evolution of the Egbe-Isanlu Schist belt. Global Journal of Geological Sciences; Vol. 1, No. $2,113-127$

Pettijohn F. J. (1957). Sedimentary rocks. New York, Harper and Brothers. $2^{\text {nd }}$ edition. 718.

Pearce M., Gorman, B.E., Birkett, T.C. (1975). The Relationship between Major Element Chemistry and Tectonic Environment of basic and intermediate Volcanic Rocks. Earth and Planetary Science Letters. 36(1), 121-132.

Rahaman, M.A. (1976): Progressive polyphase metamorphism in pelitic schists around Aiyetoro, Oyo State, Nigeria. Journal of Mineralogy and Geology. 13, 33-44.

Rahaman, M.A. (1988): Recent Advances in the Study of the Basement Complex of Nigeria in: Geological Survey of Nigeria (ed.) Precambrian Geology of Nigeria, pp. 11-41.

Roddaz, M., Viers, J., Brusset, S., Baby, P., Boucayrand, C. and Hérail, G. (2006). Controls on weathering and provenance in the Amazonian foreland basin: Insights from major and trace element geochemistry of Neogene Amazonian sediments. Chemical Geology. 226(1):31-65.

Roser, B.P. and Korsch, R.J. (1986). Determination of tectonic setting of sandstone-mudstone suites using $\mathrm{SiO}_{2}$ content and $\mathrm{K}_{2} \mathrm{O} / \mathrm{Na}_{2} \mathrm{O}$ ratio. The Journal of Geology. 1986; 94(5):635-650.

Turner D.C. (1983): Upper Proterozoic Schist Belts in the Nigerian Sector of the Pan-African Province of WestAfrica. In: C. A. Kogbe "Geology of Nigeria" 2nd Revised Edition, Rock View Publication Company, Jos, Nigeria. 93-109.

Van de Kamp, P.C. (1968). Geochemistry and origin of metasediments in the Haliburton Modic area, south-eastern Ontario, Canada J. Earth Sci. 5(6):1127-1136.

Weaver, C. E. (1989): Clays, muds and shales. Elsevier; Amsterdam, 820. 


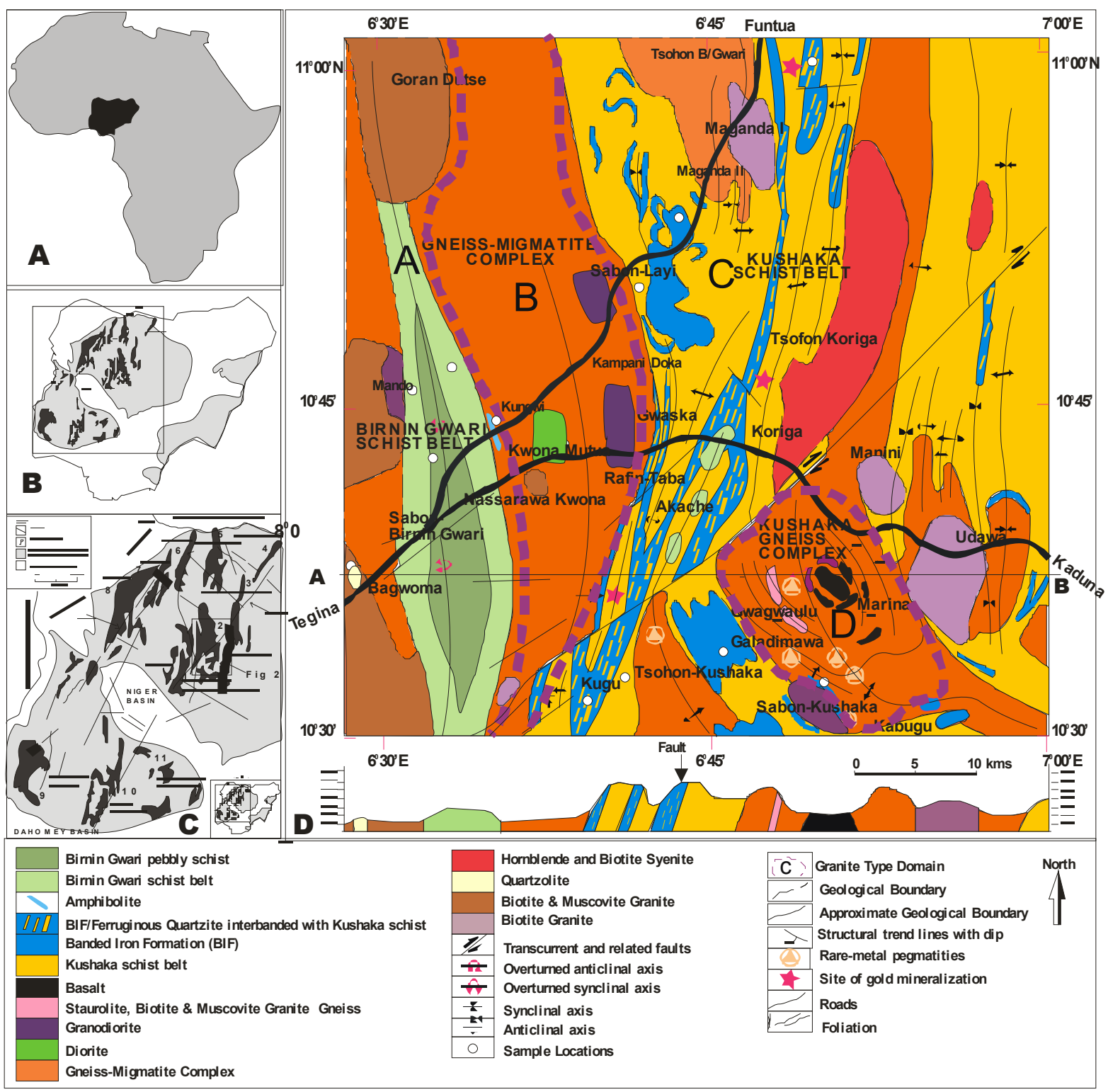

Fig. 1: Geological map of northern part of Kushaka and Birnin Gwari schist belts (Sheet 122) Modified after Truswell and Cope, (1963). 

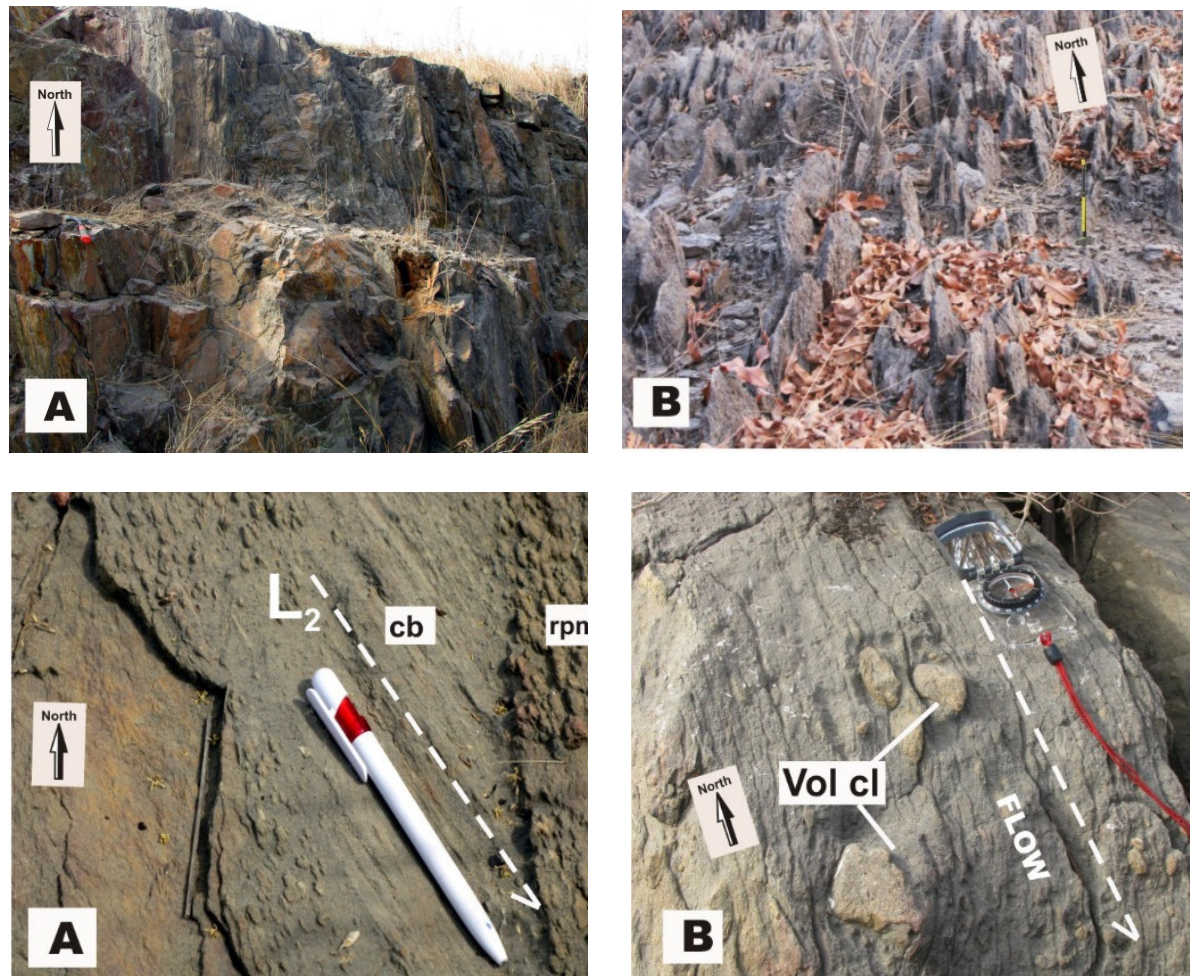

Fig. 2: Field occurrence of (A): Greyish Sabo-Layi biotite schist (N10 ${ }^{0} 49$ ' 38" E 6 $0^{0} 42$ ' 02") in Kushaka schist belt (B): Ferruginous quartzite outcrop in Maganda with vertical dips and well defined schistocity (N10 $58^{\prime} 18^{\prime \prime}$ E 6047 ' 43"). (AB): Birnin Gwari staurolite and biotite, quartz schist with Lithic (angular to rounded clastic quartz, schistose, volcanic and quartzo-feldspathic) sandstones (N10 42 ' 48" E $\left.6^{0} 33^{\prime} 42^{\prime \prime}\right)$. cb=cross bedding; vol $\mathrm{cl}=$ volcanic clast; $\mathrm{rpm}=$ ripple marks; $\mathrm{L}_{2}=$ lineation.
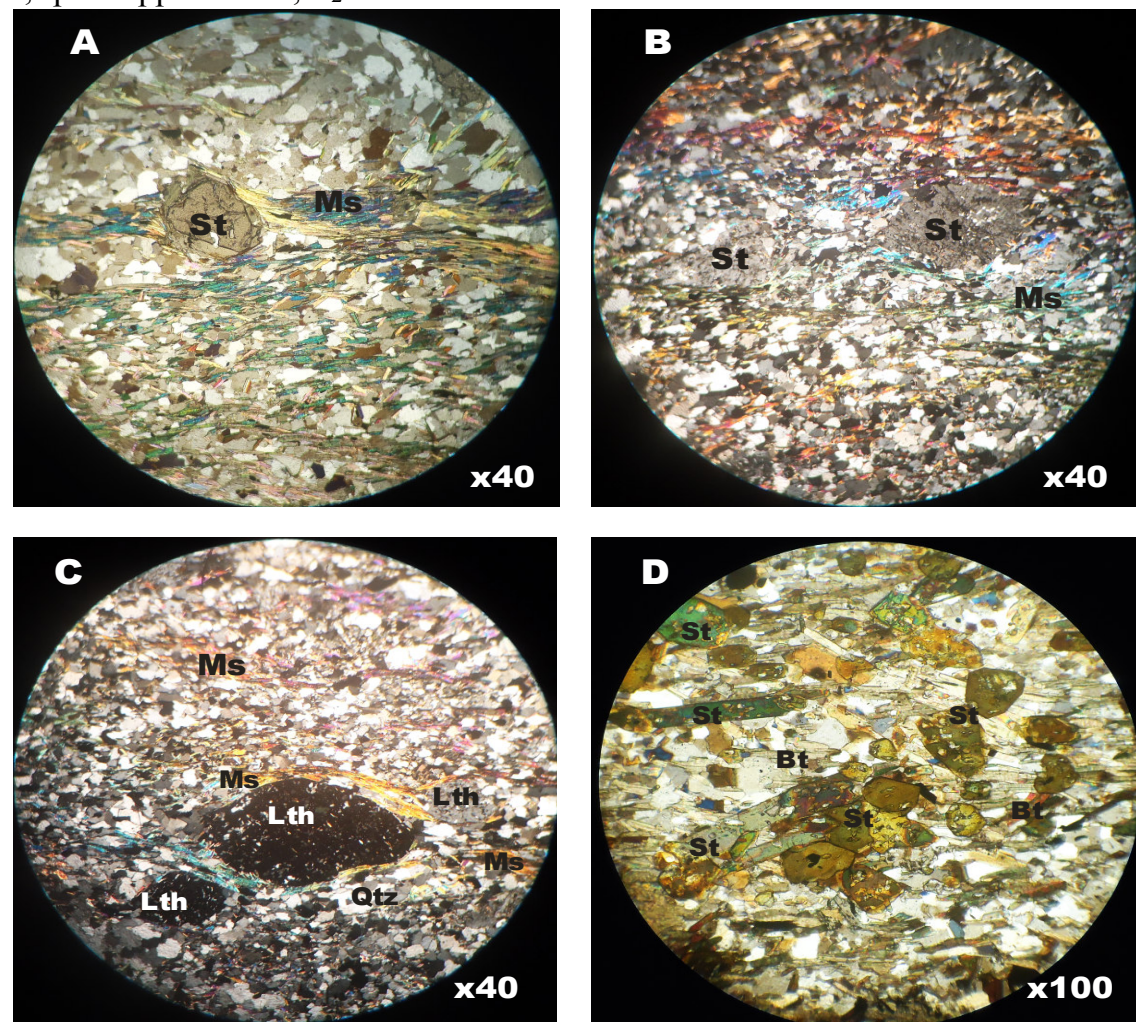

Fig. 3: Photomicrograph of (A\&B): Kugu Staurolite and Muscovite Quartz Schist; in the Kushaka Schist Belt and (C): Staurolite-Muscovite Quartz Schist with lithic materials and (D): Staurolite-Biotite Quartz Schist in the Birnin Gwari Schist Belt. St=Staurolite, $\mathrm{Ms}=$ Muscovite, $\mathrm{Bt}=$ Biotite. Lth=Lithic (angular to rounded clastic quartz, schistose, volcanic and quartzo-feldspathic) sandstones. 

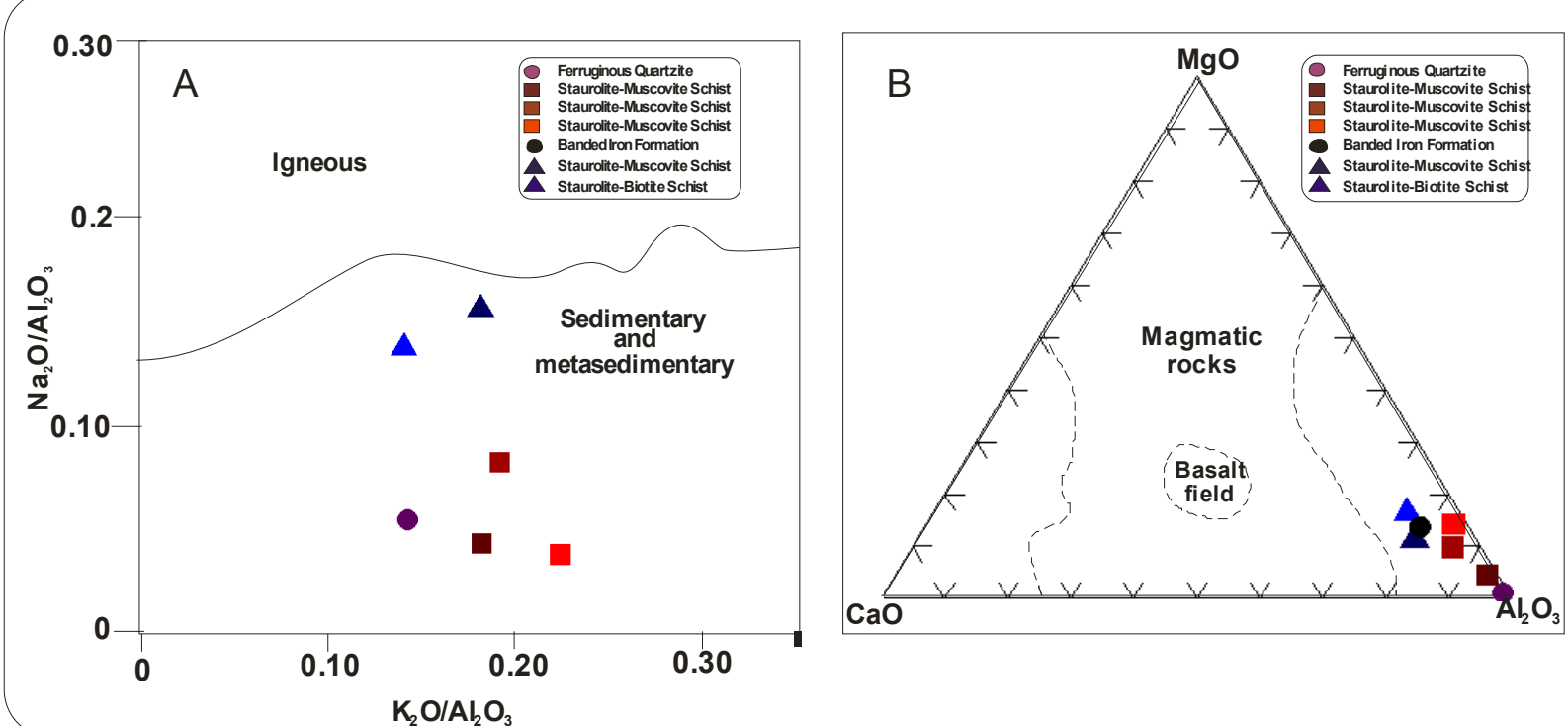

Fig. 4: (A): $\mathrm{Na}_{2} \mathrm{O} / \mathrm{Al}_{2} \mathrm{O}_{3}$ against $\mathrm{K}_{2} \mathrm{O} / \mathrm{Al}_{2} \mathrm{O}_{3}$ plot (after Garrells and Mackenzie, 1971) and $\mathrm{MgO}-\mathrm{CaO}-\mathrm{Al}_{2} \mathrm{O}_{3}$ ternary plot (after Leyleroup et al., 1977) of metasediments in the study area.
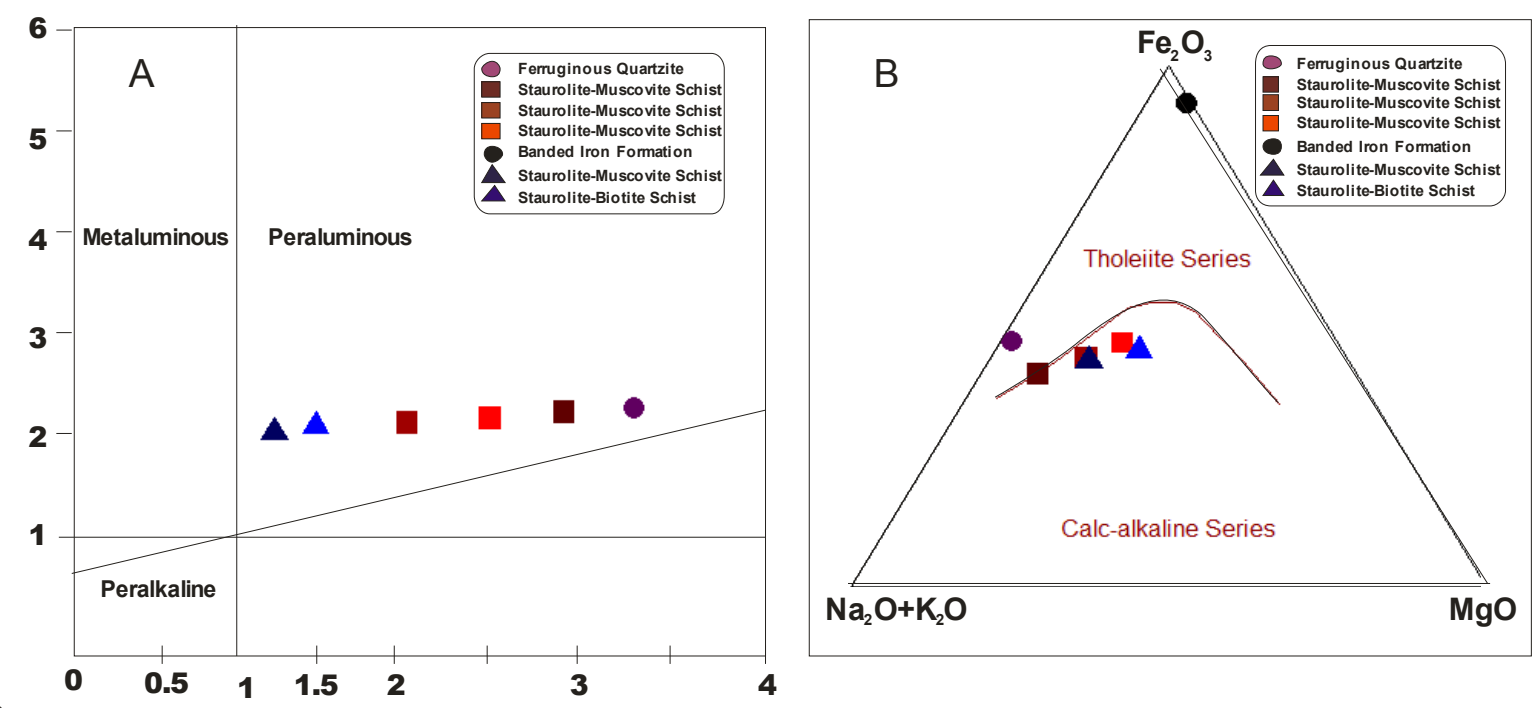

Fig.5: (A): $\mathrm{Al}_{2} \mathrm{O}_{3} /\left(\mathrm{CaO}+\mathrm{Na}_{2} \mathrm{O}+\mathrm{K}_{2} \mathrm{O}\right)$ versus $\mathrm{Al}_{2} \mathrm{O}_{3} / \mathrm{Na}_{2} \mathrm{O}+\mathrm{K}_{2} \mathrm{O}$ plot of dominantly Peraluminus nature of metasediments (after Maniar and Piccoli, 1989) and (B): AFM plot (after Irvine and Baragar, 1971) of metasediments in the study area. 

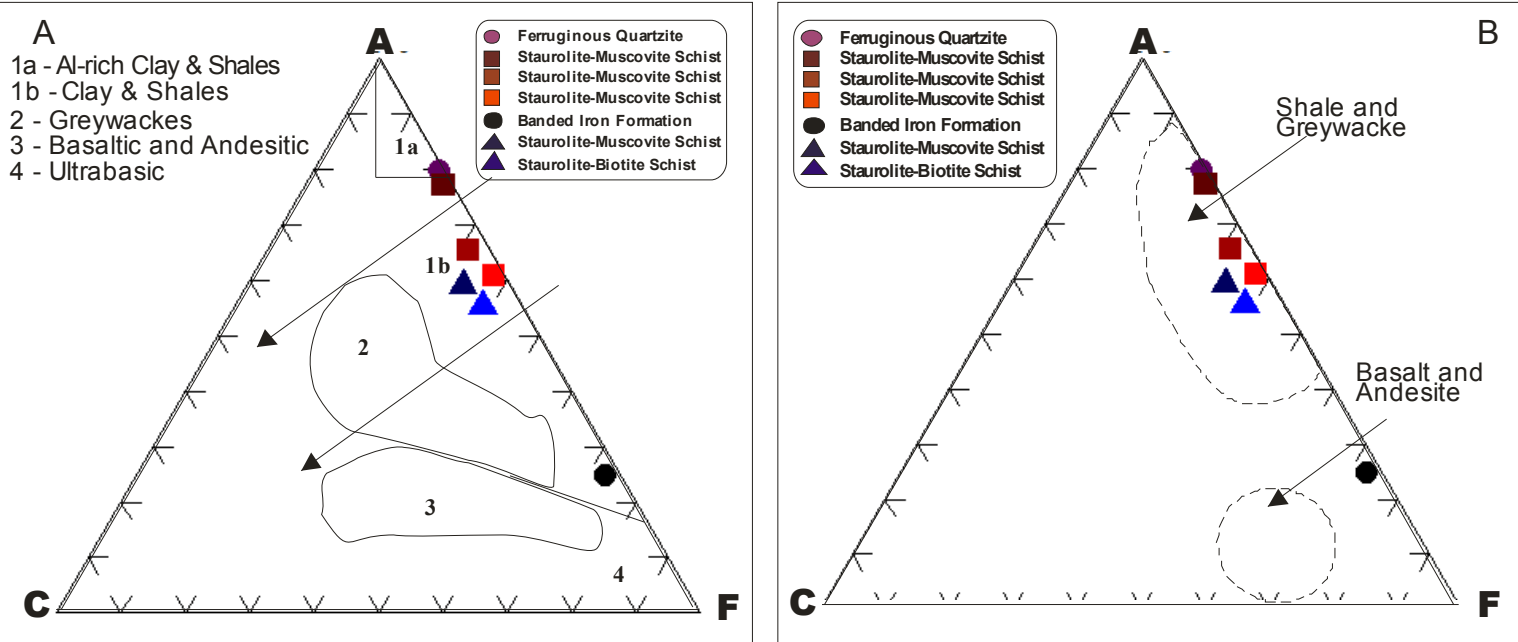

Fig.6: (A): ACF plot (after Winkler, 1967) (1a: Al-rich clays and shales; 1b: clays and shales either free of carbonate, between arrows marks containing 35-65 carbonate; 2: Greywacke; 3: basaltic and andesitic; 4: Ultrabasic) and (B): ACF plot (after Miyashiro, 1973) of metasediments in the study area.
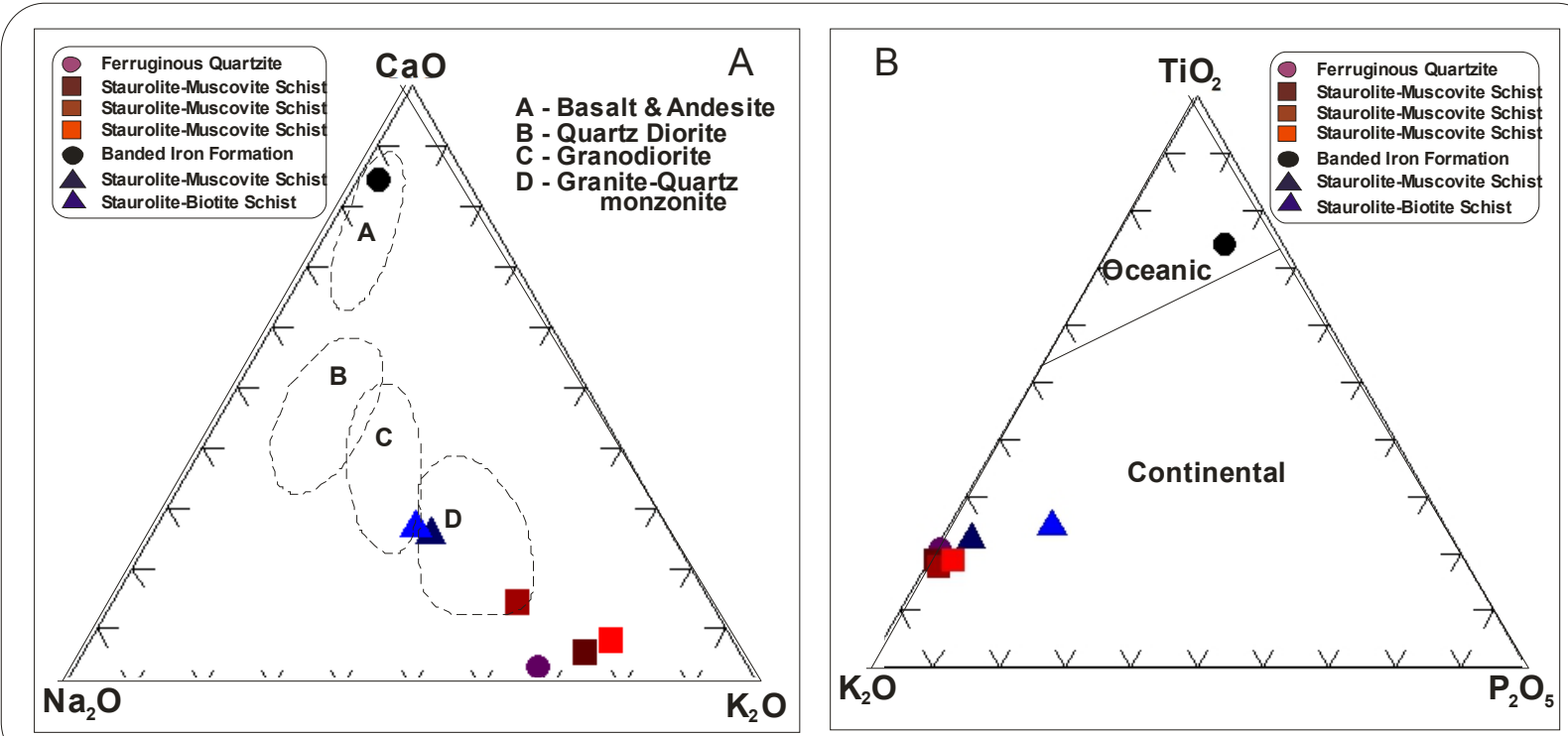

Fig. 7: (A): $\mathrm{CaO}-\mathrm{Na}_{2} \mathrm{O}-\mathrm{K}_{2} \mathrm{O}$ ternary diagram (after Condie, 1967) and $\mathrm{TiO}_{2}-\mathrm{K}_{2} \mathrm{O}-\mathrm{P}_{2} \mathrm{O}_{5}$ ternary plot (after Pearce et al., 1975) of the metasediments in the study area. 

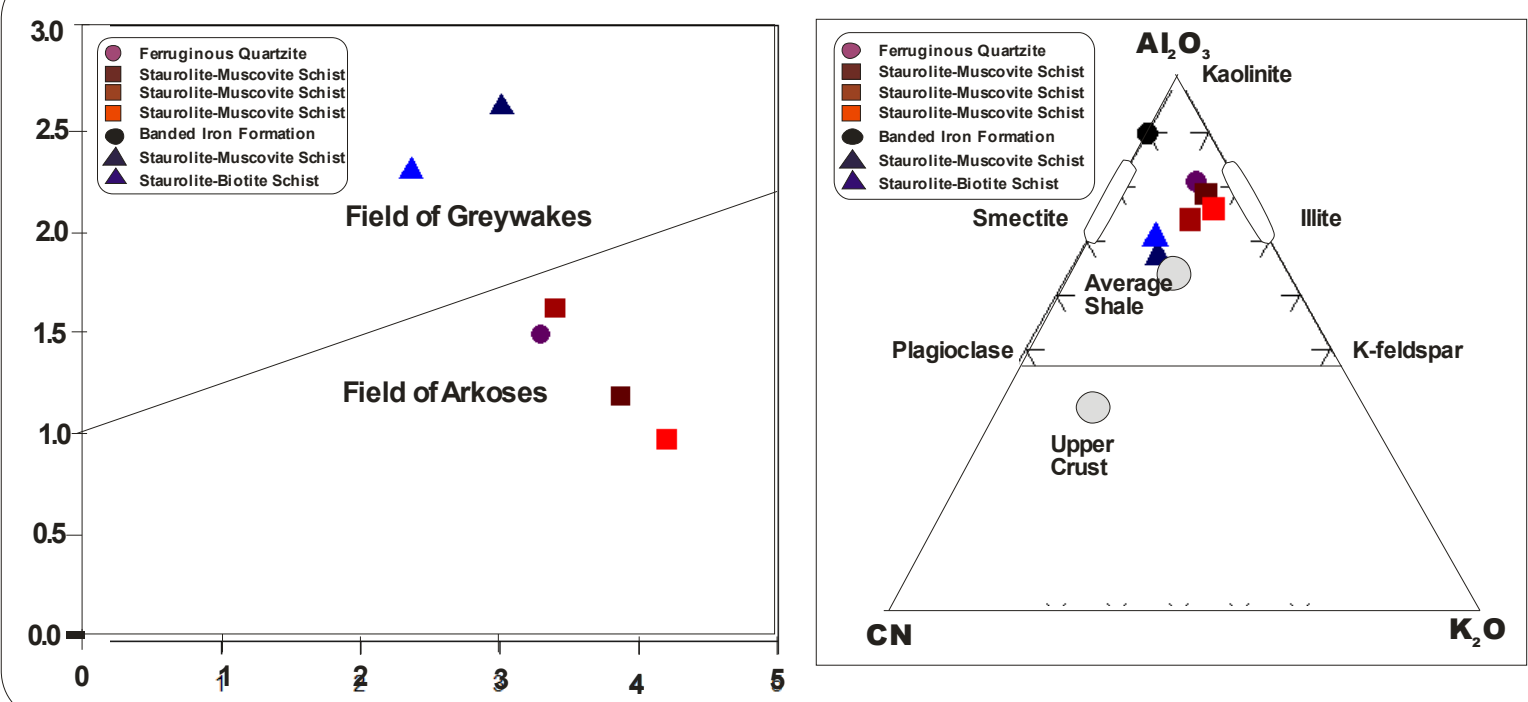

Fig. 8: (A): $\mathrm{Na}_{2} \mathrm{O}$ versus $\mathrm{K}_{2} \mathrm{O}$ plot of metasediment (after Pettijohn, 1975) and (B): $\mathrm{Al}_{2} \mathrm{O}_{3}-\mathrm{CN}-\mathrm{K}_{2} \mathrm{O}$ plot (after Pearce et al., 1975) in the study area.

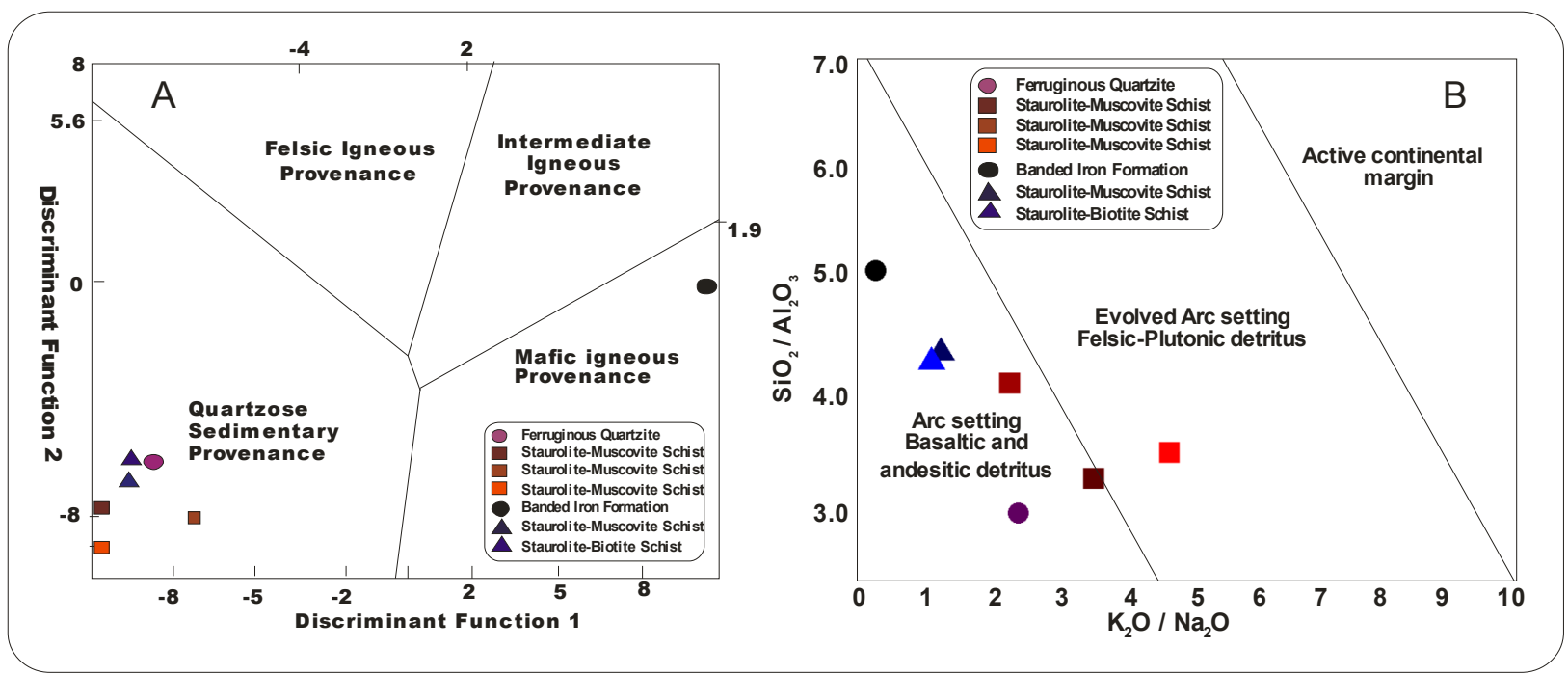

Fig. 9: (A): Discrimination Function diagram for the provenance signatures of sandstone-mudstone suite using major elements (after Roser and Korsch, 1986) and (B): $\mathrm{SiO}_{2} / \mathrm{Al}_{2} \mathrm{O}_{3}$ versus $\mathrm{K}_{2} \mathrm{O} / \mathrm{Na}_{2} \mathrm{O}$ plot of metasediments in the study area (after Roser and Korsch, 1986). 

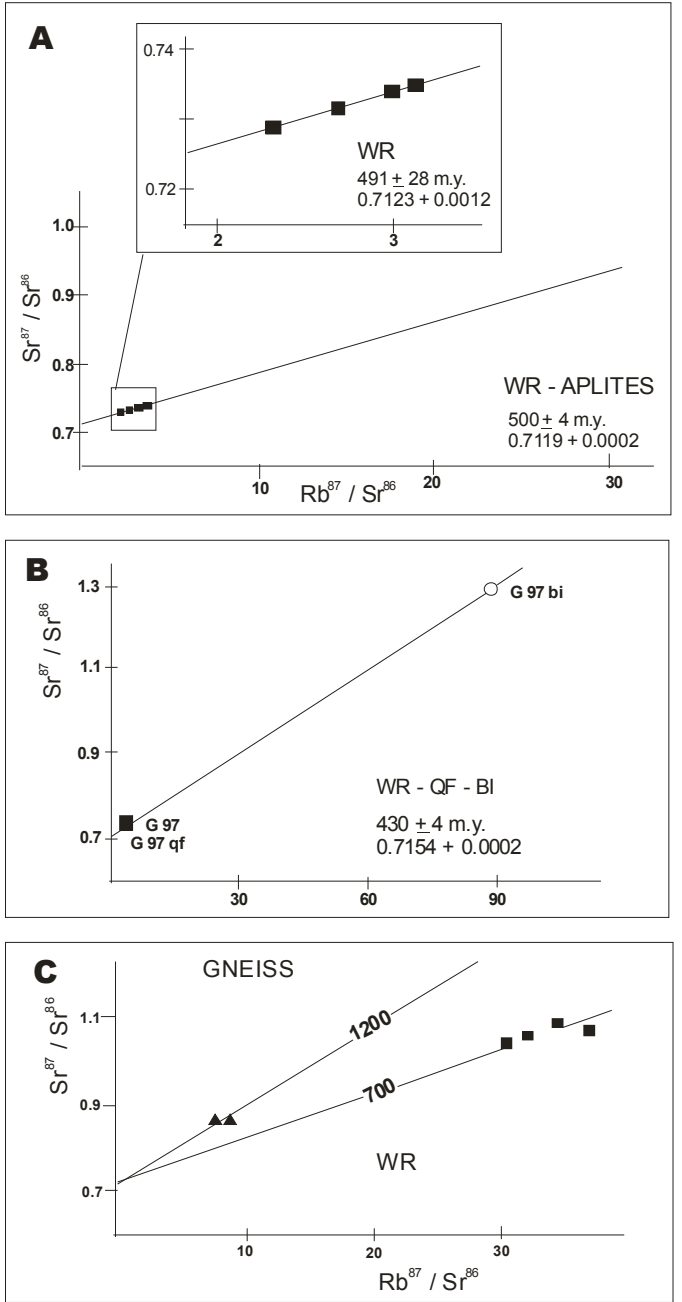

Fig. 10: Rb-Sr whole rock and mineral data (A\&B) Kusheriki granite, $20 \mathrm{~km}$ west of Birnin Gwari; (C) Granitic augen gneiss, Sabon Gayam, Kushaka (Grant et al., 1972; Grant, 1978).

Table 1: Average Modal Composition of schists and quartzite in parts of Kushaka and Birnin Gwari Schist Belts

\begin{tabular}{|c|c|c|c|c|c|c|}
\hline Mineral & KKFQ 1 & KKSc 1 & KKSc 2 & KKSc 3 & KBGSc 1 & KBGSc 2 \\
\hline Quartz & 35 & 30 & 30 & 30 & 30 & 20 \\
\hline Plagioclase & 10 & 5 & 10 & 5 & & 5 \\
\hline K-feldspar & 35 & 20 & 35 & 25 & 20 & 30 \\
\hline Staurolite & & 30 & & 15 & 30 & 25 \\
\hline Biotite & 5 & & 20 & & & 10 \\
\hline Muscovite & & 10 & & 15 & 10 & \\
\hline Iron-oxide & 10 & 5 & 5 & 5 & 5 & 5 \\
\hline Accessory & 5 & & & 5 & 5 & 5 \\
\hline Total & 100 & 100 & 100 & 100 & 100 & 100 \\
\hline
\end{tabular}


Table 2: Major elements (wt \%) abundance in the schsts, quartzite and BIF in parts of Kushaka and Birnin Gwari Schist Belts

\begin{tabular}{|c|c|c|c|c|c|c|c|}
\hline Sample & KKFQ 1 & KKSc 1 & KKSc 2 & KKSc 3 & KBGSc 1 & KBGS 2 & KKBIF \\
\hline$(\%)$ & Ferru Q/tzite & Schist & Schist & Schist & Schist & Schist & BIF \\
\hline $\mathrm{SiO}_{2}$ & 62.61 & 64.2 & 65.99 & 61.23 & 65.13 & 63.03 & 50.98 \\
\hline $\mathrm{TiO}_{2}$ & 0.87 & 0.9 & 0.74 & 1.01 & 0.92 & 0.97 & 0.34 \\
\hline $\mathrm{Al}_{2} \mathrm{O}_{3}$ & 20.93 & 19.72 & 16.53 & 17.71 & 15.4 & 15.16 & 10.47 \\
\hline $\mathrm{Fe}_{2} \mathrm{O}_{3}$ & 4.92 & 4.58 & 6 & 7.96 & 6.62 & 7.3 & 29.22 \\
\hline $\mathrm{MnO}$ & 0.08 & 0.05 & 0.13 & 0.07 & 0.11 & 0.12 & 5.19 \\
\hline $\mathrm{MgO}$ & 0.18 & 0.93 & 1.87 & 2.97 & 2.17 & 3.31 & 1.82 \\
\hline $\mathrm{CaO}$ & 0.17 & 0.32 & 0.84 & 0.45 & 1.93 & 1.69 & 1.02 \\
\hline $\mathrm{Na}_{2} \mathrm{O}$ & 1.49 & 1.19 & 1.62 & 0.98 & 2.6 & 2.29 & 0.15 \\
\hline $\mathrm{K}_{2} \mathrm{O}$ & 3.3 & 3.87 & 3.4 & 4.2 & 3.01 & 2.36 & 0.04 \\
\hline $\mathrm{P}_{2} \mathrm{O}_{5}$ & 0.03 & 0.05 & 0.09 & 0.2 & 0.19 & 0.62 & 0.08 \\
\hline $\mathrm{LOI}$ & 4.11 & 3.78 & 1.98 & 2.73 & 1.25 & 1.03 & 0.18 \\
\hline $\mathrm{Total}$ & 98.69 & 99.59 & 99.19 & 99.51 & 99.33 & 97.88 & 99.49 \\
\hline
\end{tabular}

Table 3: Trace elements (ppm) abundance in the schsts, quartzite and BIF in parts of Kushaka and Birnin Gwari Schist Belts

\begin{tabular}{|c|c|c|c|c|c|c|c|}
\hline \multirow[t]{3}{*}{ Sample } & KKFQ 1 & KKSc 1 & KKSc 2 & KKSc 3 & KBGSc 1 & KBGS 2 & \multirow{2}{*}{$\begin{array}{c}\text { KKBIF } \\
\text { Kushaka }\end{array}$} \\
\hline & \multicolumn{4}{|c|}{ Kushaka } & \multicolumn{2}{|c|}{ Birnin Gwari } & \\
\hline & $\begin{array}{c}\text { Ferruginous } \\
\text { Quartzite }\end{array}$ & $\begin{array}{l}\text { Biotite } \\
\text { Schist }\end{array}$ & $\begin{array}{l}\text { Biotite } \\
\text { Schist }\end{array}$ & $\begin{array}{l}\text { Biotite } \\
\text { Schist }\end{array}$ & $\begin{array}{l}\text { Staurolite } \\
\text { Schist }\end{array}$ & $\begin{array}{c}\text { Staurolite } \\
\text { Muscovite } \\
\text { Schist }\end{array}$ & BIF \\
\hline As & 4.2 & 3.5 & 1 & 1.5 & $<1$ & $<1$ & 5.6 \\
\hline $\mathrm{Ba}$ & 670.7 & 729.8 & 599 & 974.8 & 32.2 & 27.6 & 21.2 \\
\hline $\mathrm{Ce}$ & 39.9 & 61.4 & 57.4 & 37.7 & $<1$ & 6.2 & 10.9 \\
\hline Co & 30.1 & 25.2 & 34 & 32.1 & 0.7 & 0.3 & 1.2 \\
\hline $\mathrm{Cr}$ & 122 & 123.2 & 85.9 & 122.4 & 23.7 & 7.9 & 15.9 \\
\hline $\mathrm{Cu}$ & 23.9 & 12.2 & 21.2 & 15.9 & 210.8 & 210.6 & 219.2 \\
\hline $\mathrm{Ga}$ & 27.3 & 24.2 & 22.5 & 22.3 & 3.3 & 3.8 & 3.8 \\
\hline $\mathrm{La}$ & 13.9 & 44.3 & 36.9 & 23.1 & 9.1 & 16.4 & $<1$ \\
\hline Mo & 0.7 & 0.2 & 0 & $<1$ & $<1$ & $<1$ & $<1$ \\
\hline $\mathrm{Nb}$ & 15.2 & 14.9 & 13.4 & 12.1 & $<1$ & $<1$ & $<1$ \\
\hline $\mathrm{Nd}$ & 7.7 & 24.6 & 22.4 & 21.8 & $<1$ & 18.7 & 11.5 \\
\hline $\mathrm{Ni}$ & 6.5 & 1.5 & 17.8 & 54.7 & 2.1 & 1.8 & 2.1 \\
\hline $\mathrm{Pb}$ & 30.3 & 28.1 & 21.3 & 14.3 & 27.5 & 31.1 & 31 \\
\hline $\mathrm{Rb}$ & 150.5 & 163.7 & 153.6 & 116 & 14.4 & 13.5 & 13.2 \\
\hline Sc & 22.2 & 20.7 & 17.1 & 24.9 & $<1$ & 2.6 & $<1$ \\
\hline $\mathrm{Sn}$ & 5.8 & 7.7 & 6.6 & 7.1 & 27.1 & 35.9 & 35.3 \\
\hline $\mathrm{Sr}$ & 111.6 & 99.2 & 127.9 & 108.3 & 557.6 & 134 & 129.1 \\
\hline $\mathrm{Ta}$ & 0 & 0.7 & 0.3 & $<1$ & $<1$ & $<1$ & $<1$ \\
\hline $\mathrm{Th}$ & 16.5 & 17.2 & 12.3 & 9.2 & $<1$ & $<1$ & $<1$ \\
\hline $\mathrm{U}$ & 1.2 & 2.8 & 2.6 & 2.7 & 6.4 & 1.1 & 1 \\
\hline $\mathrm{V}$ & 114.7 & 107.8 & 106.1 & 149 & 0.4 & $<1$ & 7.1 \\
\hline $\mathrm{W}$ & 164.3 & 126.2 & 148.9 & 58.9 & $<1$ & $<1$ & $<1$ \\
\hline $\mathrm{Y}$ & 16.2 & 22.2 & 20 & 31.9 & 2.9 & 3.6 & 4 \\
\hline $\mathrm{Zn}$ & 32.5 & 45.6 & 85.9 & 109.1 & 32.7 & 41.9 & 44.6 \\
\hline $\mathrm{Zr}$ & 187.3 & 205.9 & 201.7 & 212.6 & 35.3 & 28.3 & 27.6 \\
\hline CIA & 80.84 & 78.56 & 73.36 & 75.87 & 67.13 & 70.51 & 89.64 \\
\hline !CV & 0.52 & 0.59 & 0.87 & 0.99 & 1.12 & 1.18 & 3.11 \\
\hline
\end{tabular}

